\title{
The distribution and population of Seychelles Black Paradise-flycatcher Terpsiphone corvina on La Digue: implications for conservation and translocation
}

DAVE CURRIE, RACHEL BRISTOL, JAMES MILLETT and NIRMAL JIVAN SHAH

\begin{abstract}
Summary
The $10 \mathrm{~km}^{2}$ island of La Digue, Republic of Seychelles, western Indian Ocean supports the last viable population of the Critically Endangered Seychelles Black Paradise-flycatcher Terpsiphone corvina. Small populations recorded on adjacent islands since the 1980s appear to be ephemeral and not self-sustaining. We document the results of the first island-wide survey of the flycatcher on La Digue using the playback of conspecific calls at random points. Previous surveys were based largely on counting the number of singing males. The survey was conducted between April and August 2001 and confirmed (i) the current world population is at least 200 individuals (109-145 territories, 218-290 individuals) in a c. $4.4 \mathrm{~km}^{2}$ range, thus accurately quantifying the documented increase in flycatcher numbers since the late 1970s; (ii) territories were more widely distributed than previously recorded and not exclusively associated with coastal plateaux or freshwater bodies, contrary to previous descriptions; and (iii) distribution was determined largely by the presence of high canopy (native) broad-leaved tree species. The importance of canopy height to flycatchers was highlighted by the fact that localized loss of high canopy (native) forest $(4 \%)$, in a 161 ha study area on the large western plateau, resulted in an equivalent reduction $(4 \%)$ in the number of territories. In light of our findings we discuss the implications for conservation of the flycatcher on La Digue and its possible translocation.
\end{abstract}

\section{Introduction}

Seychelles Black Paradise-flycatcher Terpsiphone corvina (Newton 1867) is classified as Critically Endangered on the basis of small population size and restricted range (BirdLife International 2000). Historically, the flycatcher was found on at least five of the inner (granitic) islands in the Seychelles archipelago, western Indian Ocean (Figure 1), but currently the only viable population is on the 10 $\mathrm{km}^{2}$ island of La Digue (69-85 territories, c. 150-200 individuals; Rocamora 1997). Small and apparently ephemeral populations have been periodically recorded on adjacent islands, for example $c$. three individuals were recently rediscovered after a documented absence of 60 years on the $0.9 \mathrm{~km}^{2}$ island of Marianne (Parr and Shah 1998). Creation of additional self-sustaining populations is considered 


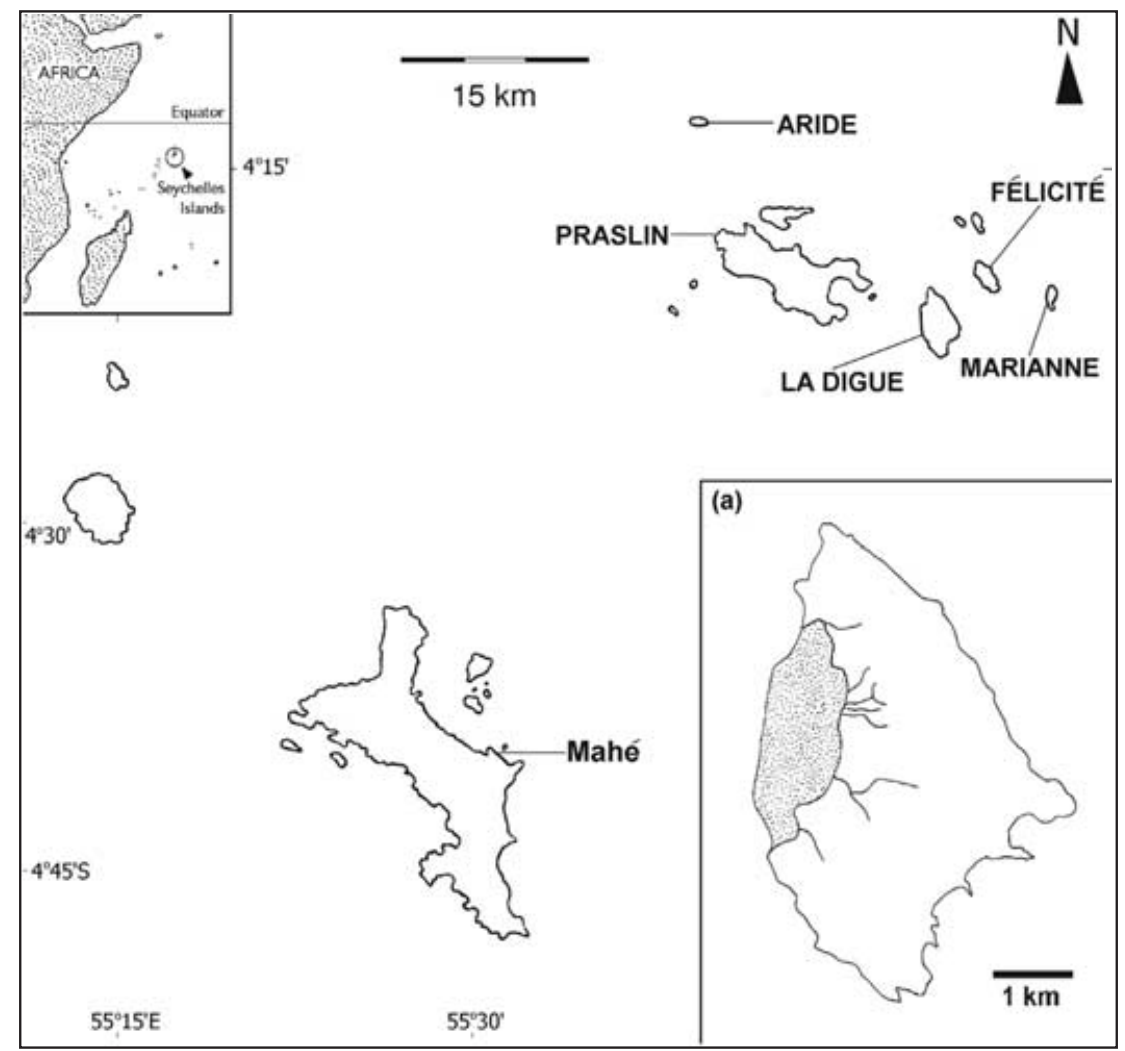

Figure 1. Documented historical range of the Seychelles Black Paradise-flycatcher from Collar and Stuart (1985), Diamond (1984), and Watson (1991). Map shows Seychelles inner archipelago: islands titled in bold upper-case were within the flycatcher's documented historical range. Inset (a) shows La Digue and the 161 ha study area (shaded) encompassed by the canal, and the seven rivers, which run into it.

important in improving the conservation status of the species (Watson 1984, 1991, Rocamora 1997).

Most authors have considered the flycatcher to be largely restricted to coastal plateaux and implicitly associated with, or dependent on freshwater marshes (e.g. Collar and Stuart 1985, Watson 1991). Most pairs on La Digue have been reported from the five coastal plateaux, and mainly on the largest (220 ha) western plateau (Watson 1991, Rocamora 1997). As a consequence, recommended conservation actions, both to secure the population on La Digue and to increase the range by establishing additional populations have concentrated on plateau wetland conservation and reintroduction to islands with extensive marshes. However, recently there have been increasing numbers of reports of individuals seen off plateau, which coincide with a documented two-fold increase in the population in the last 12 years (Watson 1991, Rocamora 1997). In addition, recent research suggests an overemphasis on the importance of freshwater wetland areas (Currie et al. in press). The occurrence of a significant proportion of the 
population away from plateau and wetland areas has implications for future conservation policy.

In this paper we describe the first random-point baseline survey of the flycatcher on La Digue (using the playback of conspecific calls), identify factors that may explain its distribution on La Digue, and produce a population estimate based on quantifiable flycatcher-habitat associations. In light of our findings we discuss the implications for future conservation measures.

\section{Methods}

\section{Selection of random squares}

The 1:1000o Ordnance Survey (OS) map of La Digue (Series Y851 D.O.S. 204, Edition 3-OSD 1984) was divided into a $200 \mathrm{~m} \times 200 \mathrm{~m}$ grid within the existing $1,000 \mathrm{~m} \times 1,000 \mathrm{~m}$ grid. Each square containing more than $50 \%$ land was sequentially numbered. Random squares were selected using a random number generator.

\section{Measuring characteristics of random squares}

The mid-point of each randomly selected square was located in the field using compass bearings on distinctive landscape features. The following habitat characteristics were noted: (i) species composition of the nearest 20 trees (diameter at breast height $>10 \mathrm{~cm}$ ), (ii) distance from the mid-point of the square to furthest tree $(\mathrm{m})$ from which a measure of tree density (number of trees $/ \mathrm{m}^{2}$ ) was calculated (density $=$ number of trees/area, where area $=\pi \mathrm{r}^{2}$ and $r=$ distance to furthest tree), (iii) understorey composition measured as the number of contacts at $1 \mathrm{~m}$ height intervals (0-1, 1-2 and 2-3 $\mathrm{m}$ ) at the mid-point of the square and at $5 \mathrm{~m}$ north, south, east and west from the mid-point. This was subsequently expressed as the total number of contacts of natives and non-natives, and (iv) canopy height at the same five points from which a mean canopy height was calculated.

Other characteristics of each random square were measured from the above OS map. These were: (i) distance from mid-point of square to the nearest river/ marsh (m), (ii) length of river/marsh in each square, (iii) height above sea level (measured at the mid-point of each square), and (iv) maximum range in height. The dominant vegetation type was assigned for each random square from a recent vegetation map of La Digue (GIS, Ministry of Environment [MOE] 2001). Vegetation was grouped into one of four categories based on MoE's original classifications: (i) mixed forest (comprising a mixture of native introduced and endemic broad-leaved vegetation), (ii) bush vegetation, (iii) coconut dominated forest, and (iv) cultivated and urban areas.

\section{Playback}

The survey was conducted April-August 2001 using the playback of conspecific calls. Playback comprised a mixture of male song and solicitation calls, which 
had previously been demonstrated to be effective at attracting birds to mist-nets (Currie et al. in press). Approximately 90\% of territories on the western plateau had at least one member of the pair colour-ringed, and random squares sampled on the plateau $(n=12)$ provided the baseline for interpretation in response to playback. At least one colour-ringed individual from each territory encompassing random squares was observed to respond to playback.

The same tape-player was used throughout the survey and volume and tone were kept constant. Tape volume was sufficient to be heard by the human ear at least $100 \mathrm{~m}$ away during relatively calm conditions. The survey was not conducted in very windy and/or rainy conditions when audibility may have been affected.

Playback was conducted for $5 \mathrm{~min}$ north and then $5 \mathrm{~min}$ south at the mid-point of each square between oghoo and 16hoo. The same recording was used for each period of sampling. During playback the number of birds that responded and the direction they responded from were noted, to give an estimate of the number of territories in each square. If a bird was detected during the 5 min of playback facing north, playback was still conducted to the south taking care to distinguish between individuals. Unringed males were distinguished on characteristics of the two long central tail feathers (after Watson 1991, Rocamora 1997). Current data indicate that flycatcher territories are on average 1.04 ha \pm 0.07 (S.E.), range $0.4-2.46$ ha (Currie et al. in press). Mid-points of neighbouring squares were 200 $\mathrm{m}$ apart, reducing the likelihood of counting the same individuals in neighbouring squares. The presence/absence of flycatcher in non-random squares was also opportunistically noted using playback and observation. Site and map features of non-random squares were not recorded and presence/absence data for these squares were not used in the calculation of population estimates.

\section{Mapping of territories in study area}

The locations of flycatcher territories on 161 ha of the $c .220$ ha western coastal plateau of La Digue, being that part of the plateau encompassed by the canal (see Figure 1), were mapped from a recent aerial photograph (1997, Ministry of Land Use and Habitat, scale 1:2000). Territories were mapped using nest locations, the location of colour-ringed and singing males, or unringed males identified by variation in tail feathers (see Watson 1991, Rocamora 1997).

\section{Data analyses}

Data were analysed using SPSS (Norusis 1992). Binary logistic regression was used to examine factors accounting for the presence/absence ( 1 or o) of flycatchers, $F$ to enter $P<0.05, F$ to remove $P>0.1$. Three models (all $F$ to enter $P$ $<0.05, F$ to remove $P>0.1$ ), were considered: one was based on habitat features of square measured from the above OS maps, another solely on site variables. A third incorporated both map and site variables. Variables were only entered into the multivariate model if their univariate significance had $P<0.25$ (Hosmer and Lemeshow 1989). Biologically meaningful first-order interactions were included in the original model. Non-significant factors and interactions were 
removed, the least significant first, until only significant factors and/or interactions remained.

\section{Results}

\section{Island survey}

Playback was conducted in $76(30 \%)$ of 252 possible squares. Flycatchers were detected in $33(43 \%)$ of the random squares sampled (see Figure 2): 66\% (22) of squares with flycatchers were estimated to contain one territory and $33 \%$ (11) were estimated to contain two.

No variables were significant in explaining flycatcher distribution using the map based model. In both the site-based and the combined map/site model canopy height was the only significant variable explaining the presence of flycatchers, and individuals were more likely to be detected in high canopy (broad-leaved) woodland (mean canopy height \pm S.E. with flycatchers present $=$ $17.69 \mathrm{~m} \pm 1.48$, with flycatchers absent $=11.72 \mathrm{~m} \pm 1.21$; Wald statistic $=7.71, d f=$ $1, P<0.01)$.

The lack of significant map variables explaining the distribution of flycatchers meant that remote predictions of population estimates could not be made. However, on the basis of detection rates in the squares sampled, we predicted that flycatchers would be present in a maximum of 109 squares across the whole island. This results in a population estimate, assuming a minimum of one territory per square, of 109-145 territories (218-290 individuals) in $4.38 \mathrm{~km}^{2}$. Although altitude did not explain the presence of flycatchers in random squares (mean detection altitude \pm S.E. $=60.2 \mathrm{~m} \pm 10.6)$, the density of territories was higher on the plateau with $0.52-0.78$ territories per square on plateau $(<10 \mathrm{~m}$ asl $)$ versus $0.38-0.47$ territories per square off plateau. A revised population estimate taking into consideration the higher density of flycatchers on plateau resulted in an almost identical estimate of 109-146 territories (208-292 individuals) in a 4.38 $\mathrm{km}^{2}$ range.

Flycatcher presence was confirmed in at least 87 random and non-random squares visited during the survey, equivalent to at least $87-115$ territories (174230 individuals), giving credence to a revised population estimate in excess of 100 territories (200 individuals).

\section{Distribution and number of birds on western plateau}

Sixty-three territories were identified in the study area on the western plateau in June 1999 and showed a small decline to 59 territories by October 2001 (see Figure 3). In the previous most recent survey, there were 48 confirmed territories in the same area (Rocamora 1997). The loss of territories in the current study 1999-2001 corresponds to localized habitat removal due to development or extensive habitat degradation due to takamaka wilt disease, a fungus which causes defoliation and death of takamaka Calophyllum inophyllum (Ivory and Andre 1994, Ivory et al. 1996). Territories remained relatively constant in areas not affected by habitat loss or degradation. 


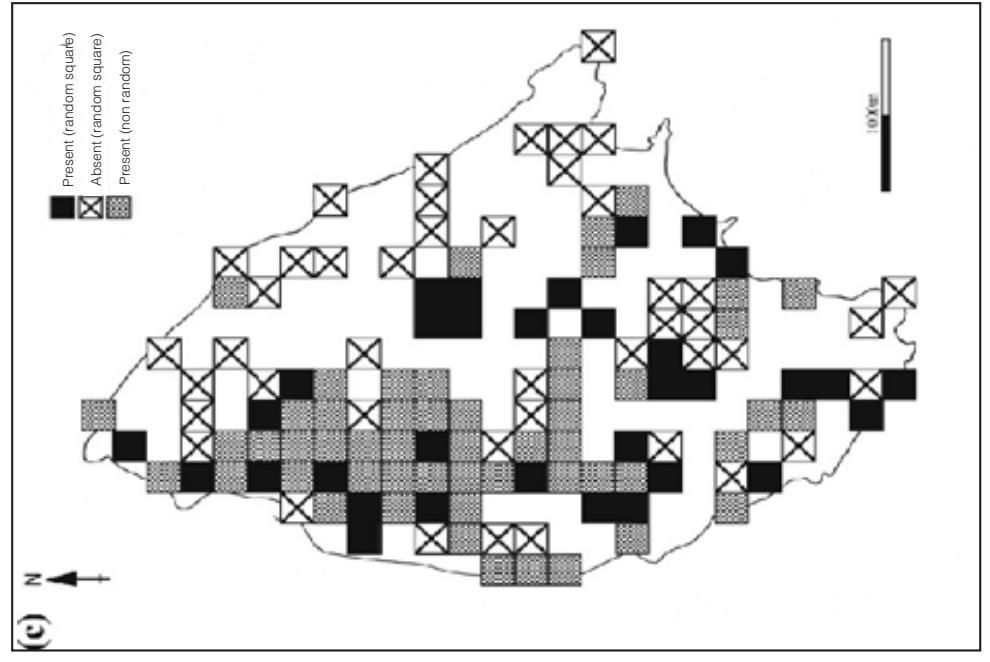

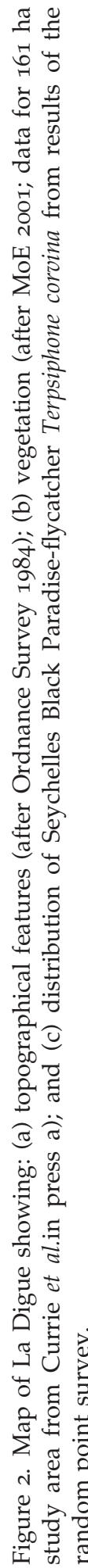
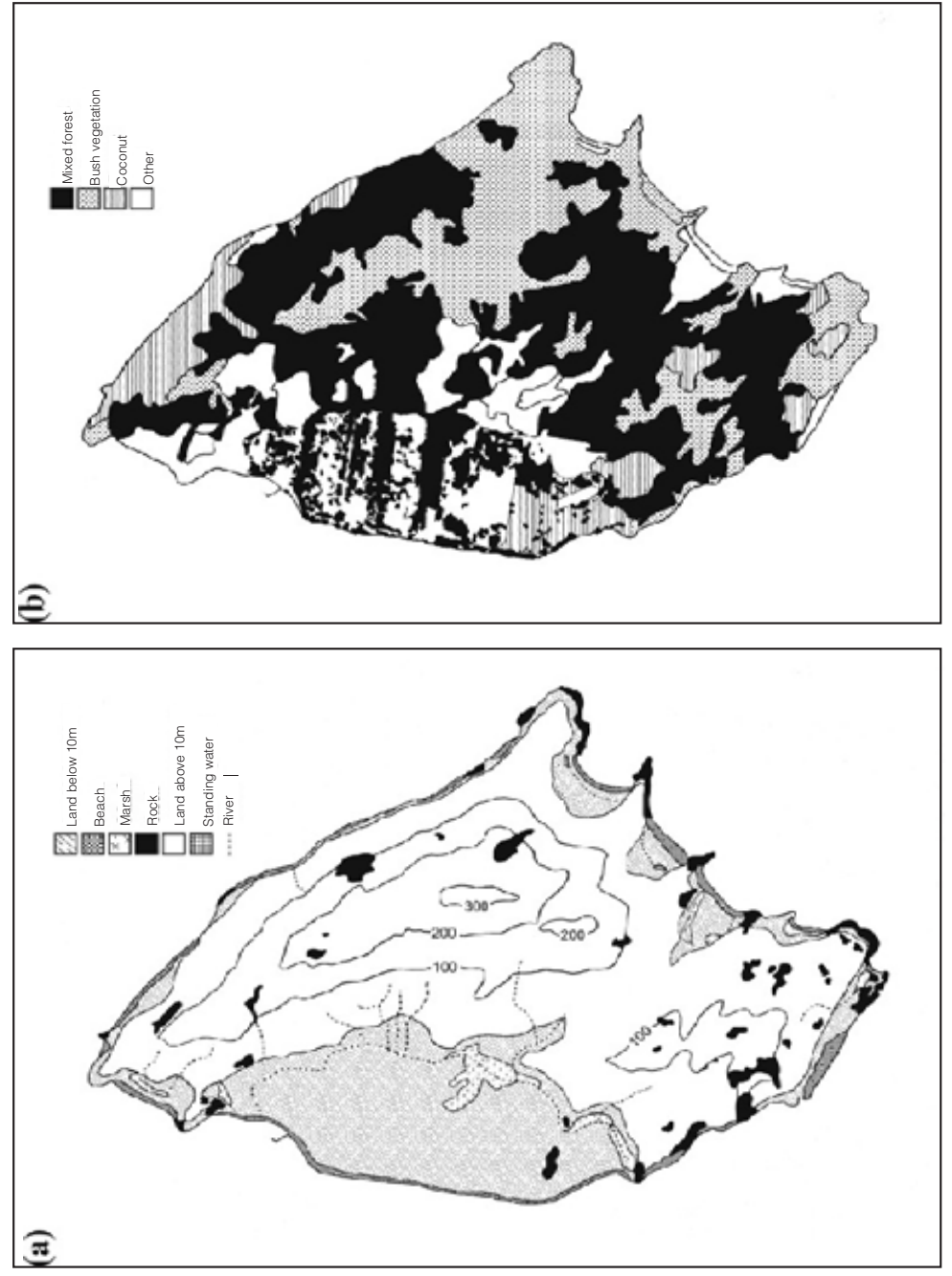


\section{Discussion}

The island-wide survey of La Digue in 2001 revealed several new areas containing flycatchers, particularly at the south of the island, while the first colour ringing programme on the western plateau population since the 1980s (see Watson 1991) revealed significantly more territories than previously documented. We estimate that the current population of Seychelles Black Paradiseflycatcher is in excess of 200 individuals (109-145 territories, 218-290 individuals). The previous most recent estimate (for 1996) was 69 confirmed territories plus 16 probable territories (138-175 individuals), subsequently extrapolated to C. 150-200 individuals (Rocamora 1997).

\section{Flycatcher population trends}

Flycatcher numbers were characterized by a period of stasis during 1978-1988 when the population remained relatively constant at about 25 pairs, the majority of birds being found on the western coastal plateau (Watson 1981, 1991). Over the following 12 years a two-fold increase in the population was documented (Rocamora 1997). It is important to note that earlier surveys involved censusing unringed singing males, and were biased toward the plateau, frequently close to areas in proximity to roads and paths. However, there is little doubt that there has been a significant increase in flycatcher numbers since the rigorous studies of the 1980s (Watson 1981, 1991): flycatchers were rarely recorded away from the plateau before 1988 (J. Watson pers. comm.). Reasons for this increase remain unclear, but correspond with improved species awareness and protection, in particular the banning of catapults (in 1991). The current study further confirms this increase, and the higher population estimate can be explained in light of a larger plateau population and detecting birds in previously unsurveyed areas off plateau. Colour ringing conducted during 1999-2001 showed that there were $30 \%$ more confirmed territories in the 161 ha study area than previously documented (Rocamora 1997, Currie 2002, Currie et al. in press).

\section{Factors determining the distribution of flycatchers}

The presence of high canopy broad-leaved forest, dominated by native tree species, was the primary factor explaining the distribution of flycatchers on La Digue. Canopy-forming broad-leaved forest was probably the original vegetation of the plateaux, low-medium hill slopes and river valleys of all but the smallest granitic islands. This finding is consistent with the historical distribution of the flycatcher on islands, such as Félicité and Marianne, which have small plateaux and small wetlands, but were historically dominated by low to mid-altitude native forest (Vesey-Fitzgerald 1940).

We have previously shown that native plateau forest dominated by takamaka and badamier on La Digue is important in flycatcher habitat requirements (Currie et al. in press, Currie 2002; see also Bullock et al. 1987, Watson 1991, Rocamora 1997, Neufeld 1998). The importance of wetland areas for the plateau population appears to have been overemphasized and can be explained, at least in part, by a non-random association between the distribution of preferred forest 


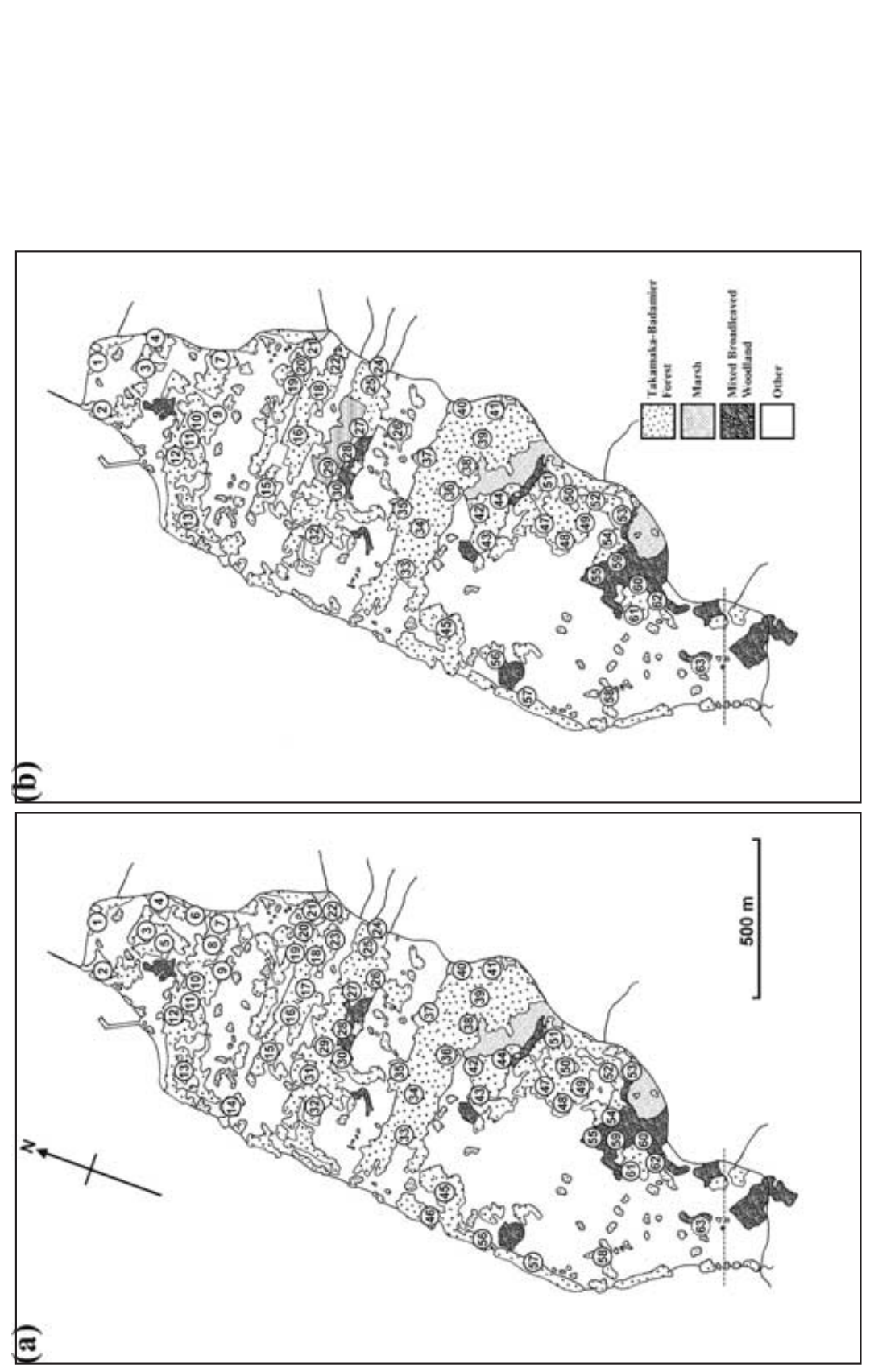


habitat and wetlands (Currie et al. in press). Similarly, during the island-wide survey there were no significant direct quantifiable associations between the presence of flycatchers and water-related features of random squares e.g. distance to river/marsh, or length of river/marsh within random squares. However, flycatchers were rarely detected on the north-east side of the island even in the presence of mixed forest dominated by takamaka (see Figure 2c). This part of the island is characterized by a lower canopy forest, a steeper more exposed aspect and therefore presumably thinner soils, and generally dryer conditions.

\section{The status of off-plateau birds}

Flycatchers previously recorded on low to mid-slopes have generally been presumed to be non-breeding birds that have dispersed from the plateau population. In the current survey, active nests and pairs with dependent young were observed on low and mid-altitude woodland slopes. The recruitment of unringed birds to the western plateau study population observed June 1999-October 2001 (Nature Seychelles unpubl.) provides supporting evidence that successful breeding occurs on the hill and that it is not just a reservoir of non-breeding birds. However, the density of flycatchers was 1.3-1.6 times higher on the plateau than on the low to mid-slopes, reflecting the greater availability of preferred woodland habitat.

\section{Presence on other islands}

In recent surveys of the inner granitic islands using conspecific playback, flycatchers were only confirmed as being present on Marianne: several individuals (including a mature male in 1997) were recorded in 1997-2001 (Parr and Shah 1998, Hill 2002) although only one (female-type plumage) individual was confirmed present during an extensive island-wide search using the playback of conspecific calls in 2002 (Nature Seychelles unpubl.). There are sporadic reports of solitary individuals being seen on Félicité, and there has been at least one reliable report during the study of a "female-type plumage" flycatcher being seen on Praslin in 2001 (A. Cedras pers. comm.). Further emigration resulting in records of individuals or small populations on islands adjacent to La Digue seems probable given the high population levels and occupancy of suitable forest habitat.

\section{The importance of the plateau population}

Although flycatchers were detected over much of La Digue, the importance of the western plateau population should not be underestimated: the majority (6o$70 \%$ ) of the world population occurs in just 220 ha. The conservation of woodland on this plateau has been frequently cited as the primary factor in conserving the flycatcher on La Digue (e.g. Watson 1991, Rocamora 1997, Marshall 1997, Neufeld 1998). Watson's recommendations (1991) resulted in the purchase of 8 ha of mature plateau forest which was subsequently designated a special reserve: at the time it contained c. $20 \%$ of the world population. Additional land was purchased in 2000-2001 and the reserve currently stands at c. 21 ha, although much of the extension is unwooded marshland. This acquisition was apparently 
based on the overemphasis of the relative importance of wetlands (e.g. Gerlach 1997). However, most flycatchers (90\%) occur outside protected areas and no woodland has been planted outside the reserve to compensate for loss during the study. Between April 1999 and October 2001 c. 3 ha (c. 4\%) of woodland was lost in the 161 ha study area, through development and a wilt disease affecting takamaka (Ivory and Andre 1994, Ivory et al. 1996), resulting in a parallel reduction in the number of territories. Although this decline was small, losses of woodland in other parts of the plateau also occurred and available information suggests that the rate of development on La Digue is scheduled to increase in the future: at the time of submission, forest area had further decreased. In reality, only limited conservation actions can be implemented, despite formal protection afforded to native tree species, due to development pressure and multiple ownership of land on which this woodland occurs. As a result effective flycatcher conservation on La Digue is severely restricted.

\section{Implications for conservation and re-introduction}

Given that ongoing and planned development on plateaux appears incompatible with the long-term conservation of forest and hence any significant improvement in the conservation status of the flycatcher, the existence of a breeding population of birds in low hill forest on La Digue is important and suggests that conservation measures could be extended to areas less threatened by development. Hill populations may act as a buffer against extinction. However, La Digue currently holds the only known population of the species and the creation of additional populations off La Digue is of vital conservation importance. Reintroduction, more than ever, should be considered a priority in the conservation of the flycatcher (Watson 1991, Rocamora 1997, Currie et al. 2003). The revised higher population estimate allows the option to remove sufficient birds to maximize the chances of a reintroduction succeeding (see Lovegrove 1996), without compromising the La Digue source population.

\section{Acknowledgements}

We thank the residents of La Digue, the Ministry of Transport and Environment, and the Ministry of Land Use and Habitat for their cooperation during the study, and Kerstin Henri (GEF Project Coordinator) and Michele Martin (Education Coordinator) of Nature Seychelles for logistical support. This study was funded as part of the GEF/World Bank funded project "Seychelles Restoration of Avian Ecosystems Project" implemented by BirdLife Seychelles. Mike Hill and Tony Diamond made useful comments on an earlier version of this manuscript.

\section{References}

BirdLife International (2000) Threatened birds of the world. Barcelona and Cambridge, U.K.: Lynx Edicions and BirdLife International.

Bullock, I. D., Komdeur, J. G., Komdeur, M. D., Laboudallon, V. and Lewis, G. (1988) The Seychelles Black Paradise-flycatcher Terpsiphone corvina. Report to ICBP. 
Collar, N. J. and Stuart, S. N. (1985) Threatened birds of Africa and related islands. Cambridge, U.K.: ICBP and IUCN

Currie, D. (2002) Ecological requirements of the Seychelles Black Paradise-flycatcher Terpsiphone corvina: consequences for conservation and management. Victoria, Mahé: BirdLife Seychelles.

Currie, D., Bristol, R., Millett, J., Hill, M. Bristol, U., Parr, S. J. and Shah, N. J. (in press) Habitat requirements of the Seychelles black paradise flycatcher Terpsiphone corvina: a re-evaluation of translocation priorities. Ibis.

Currie, D., Hill, M., Millett, J., Bristol, R., Nevill, J. and Shah, N. J. (2003) Conservation options for the critically endangered Seychelles black paradise flycatcher Terpsiphone corvina. Bird Conserv. Internatn. 13: 97-114.

Diamond, A. W. (1984) Biogeography of Seychelles land birds. Pp. 487-504 in D. R. Stoddart, ed. Biogeography and ecology of the Seychelles Islands. The Hague, Boston, Lancaster: Dr W. Junk Publishers (Monographiae Biologicae 55).

Gerlach, J., ed. (1997) Seychelles Red Data Book. Seychelles: The Nature Protection Trust of Seychelles.

Hill, M.J., ed (2002) Biodiversity surveys and conservation potential of inner Seychelles islands. National Museum of Natural History, Washington., D.C.: Atoll Research Bulletin 495

Hosmer, D.W. and Lemeshow, S. (1989) Applied logistic regression. New York: Wiley.

Ivory, M. H. and Andre, W. (1994) A preliminary report of Verticillium wilt of Takamaka (Calophyllum inophyllum L.) in Seychelles. Afr. J. Mycol. Biotechnol. 3: 169-170.

Ivory, M. H., Andre, W. and Vielle, M. (1996) Wilt of Takamaka (Calophyllum inophyllum L.) in Seychelles. Phelsuma 4: 43-47.

Marshall, S. S. (1997) Future management priorities for the Seychelles Black Paradiseflycatcher (Terpsiphone corvina), La Digue, Seychelles. MSc thesis, University of Edinburgh.

Neufeld, D. (1998) Nest site use and changes in habitat of the Seychelles Black Paradiseflycatcher Terpsiphone corvina. Biol. Conserv. 84: 103-105.

Newton, E. (1867) On the land birds of the Seychelles archipelago. Ibis (2) 5:335-360.

Norusis (1992) SPSS for Windows. Advanced statistics, Release 6.1. Chicago, IL: SPSS.

Parr, S. J. and Shah, N. J. (1998) Recolonisation of Marianne island by Seychelles Paradiseflycatcher after 6o years. Bull. Afr. Bird Club 5(2): 90.

Rocamora, G. (1997) Rare and threatened species, sites and habitat monitoring programme in Seychelles. Project G1 EMPS. Seychelles: Division of Environment/BirdLife International.

Vesey-Fitzgerald, D. (1940) The birds of Seychelles. I. The endemic birds. Ibis (14) 4: 480489 .

Watson, J. (1981) The Seychelles Black Paradise-flycatcher on La Digue 1977-78. WWF Project 1590, final report.

Watson, J. (1984) Land birds: endangered species on the granitic Seychelles. Pp. 513-527 in D. R. Stoddart, ed. Biogeography and ecology of the Seychelles Islands. The Hague, Boston, Lancaster: Dr W. Junk Publishers (Monographiae Biologicae Vol. 55).

Watson, J. (1991) The Seychelles Paradise-flycatcher on La Digue: population size, habitat requirements and management options. Bird Conserv. Internatn. 1: 107-122.

DAVE CURRIE, RACHEL BRISTOL, JAMES MILLETT and NIRMAL JIVAN SHAH

BirdLife Seychelles, PO Box 1310, Victoria, Mahé, Republic of Seychelles.

Email:nature@seychelles.net and davecurrie666@hotmail.com

Received 26 March 2002; revision accepted 3 June 2003 
Appendix 1. Results of random point survey of Seychelles Black Paradise-flycatcher on La Digue, Seychelles April - August 2001. Table shows total number of squares on island ( $>50 \%$ land) in 10 $\mathrm{m}$ height intervals (Total squares), the number of random squares in which the playback of conspecific calls was conducted (No. squares sampled), and the number of squares in which flycatchers were present - data in parentheses show the estimated number of territories in each random square visited.

\begin{tabular}{lccl}
\hline Height $(\mathrm{m})$ & Total squares & No. squares sampled & $\begin{array}{l}\text { No. squares flycatchers } \\
\text { present (territories) }\end{array}$ \\
\hline $0-10$ & 90 & 27 & $14(21)$ \\
$11-20$ & 32 & 3 & $1(1)$ \\
$21-30$ & 9 & 5 & 0 \\
$31-40$ & 12 & 5 & $2(2)$ \\
$41-50$ & 7 & 3 & $1(1)$ \\
$51-60$ & 9 & 4 & $2(3)$ \\
$61-70$ & 14 & 2 & $2(3)$ \\
$71-80$ & 7 & 5 & 0 \\
$81-90$ & 6 & - & - \\
$91-100$ & 8 & 5 & $2(2)$ \\
$101-110$ & 7 & 5 & $3(3)$ \\
$111-120$ & 3 & - & - \\
$121-130$ & 8 & 4 & $2(3)$ \\
$131-140$ & 4 & - & - \\
$141-150$ & 1 & 2 & $1(2)$ \\
$151-160$ & 5 & - & - \\
$161-170$ & 4 & 1 & $1(1)$ \\
$171-180$ & 1 & - & - \\
$181-190$ & 5 & 2 & $2(2)$ \\
$>190$ & 20 & 3 & 0 \\
\hline & 252 & 76 & $33(44)$ \\
\hline
\end{tabular}

